\title{
PARTICIPATORY MANAGEMENT OF CONSERVATION AREAS
}

\author{
José Manuel Elija Guamba, PhD*
}

The management of conservation areas in some countries, has run into a growing demand for the involvement of stakeholders and communities in decision-making for the management of natural resources, particularly at local level. There are three issues around the debate: the distribution of authority and responsibilities in decision-making; the distribution of costs and benefits and issues related to sustainability at the local level (ecological, social and economic). These issues have to do with the flow of the existing distribution of the authority, responsibilities, and benefits that are not equitable and sustainable. The stakeholders and communities, require their point of views and responsibilities in decision-making for the management of natural resources are considered, and the benefits of there are shared equitably. Natural resources have always been present in discussions about the productive activities and in particular on the modes of production. The position occupied by nature into the economic discussion occurs basically due to the way in which natural resources are allocated in the production process, namely, the environmental issue has always been a problem, ultimately, inter-temporal allocation of resources between consumption and investment (Palmer, R. 2003, p. 1). This article discusses the challenges of a participatory management process of conservation areas; in search of new instruments and institutional arrangements that make effective conservation of biodiversity and ecosystems in protected areas. More specifically, the focus of the research was focused on the analysis of the relationship between the new institutional arrangements and patterns of interaction between the different actors involved in the management of conservation areas. The analytical approach was based on the theory of natural resources management and complemented by recent contributions coming from research in the political sociology, poverty and environment areas, about the phenomenon of "participation". The local dimension, while integrative synthesis between the natural and the human, historical and spatially localized, makes essential a participatory management of conservation areas in countries like Mozambique, as it allows the understanding and the transformation of social relations that are performed from a given mode of production and organization established in a defined space for protection and conservation.

INTRODUCTION......

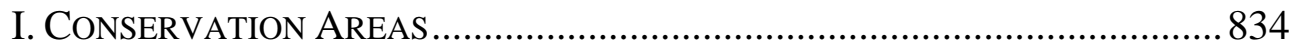

II. BIODIVERSITY AND IMPORTANCE OF ECOSYSTEMS...............................835

\footnotetext{
${ }^{*}$ Eduardo Mondlane University, Research Centre of Economics and Management, Maputo-

Mozambique. Research fields: Economics and Environmental Science. E-mail: guambej@yahoo.com.
} 
III. TROPICAL DIVERSITY 840

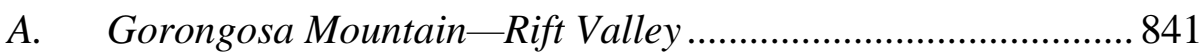

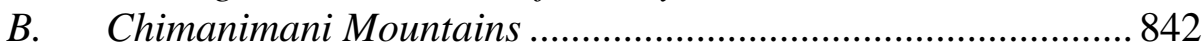

C. Centre of Endemism of Maputoland ......................................... 842

IV. LOSS OF BIODIVERSITY AND HABITAT FRAGMENTATION........................843

V. PARTICIPATORY MANAGEMENT OF CONSERVATION AREAS.....................845

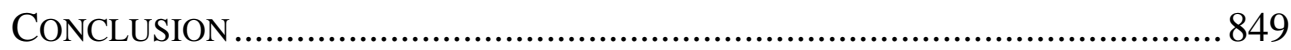

\section{INTRODUCTION}

Conservation areas are spaces that are created and established to protect and maintain the biological diversity, the natural and cultural resources, through legal instruments or other specific institutional means. These spaces are created and managed in the various levels of public administration. Within the limits and in the surroundings of these conflicting processes are intense areas and with different proportions.

According to Barbatini ${ }^{1}$, from these conflicting processes that occur in protected areas, the words "problem" and "environment" were replaced by "conflict" and "environmental and social". However, it is practically unanimous among scholars that environmental problems are forms of social conflicts, involving interests, senses and ends, in the relation between man and environment. Namely, environmental conflicts configure when the social actors defend distinct logics for the management of collective goods in common use.

The difficulties of communities sustain themselves inside or around a conservation area by not adapting to new rules that restrict land use and natural resources available, are understood here as major obstacles to the implementation of the management plan of a conservation area of sustainable use.

The control of these problems and conflicts is called management of conservation areas. According to Gohn ${ }^{2}$, developing countries face serious problems in the implementation of these management plans, making these conservation areas known as "paper parks", that is, areas imposed legally, but that has its principles compromised by the absence of a management program and management problems.

Even as protected areas, the pressures are constant and quite varied, according to possibilities of contribution to a consumer market, such as

\footnotetext{
${ }^{1}$ O. Barbatini Jr, Conflitos Socioambientais: Teoria e Prática, in ANPPAS (Indaiatuba, São Paulo 2001).

${ }^{2}$ M. Gohn, Conselhos Gestores e Participação Sociopolitica (São Paulo: Cortez 2001).
} 
illegal trade in wildlife animals, introduction of alien species or, in the case of this research, coal production to meet the basic needs of communities. Thus, the fact of being officially protected, does not guarantee a proper conservation in order to ensure the maintenance of their ecosystems.

In Gohn's ${ }^{3}$ approach, he explains that there are several research projects in conservation areas, but many are directed only to the biological aspects, being of fundamental importance for the existence of research that address social aspects constituting, together, they subsidize the elaboration of management plans, in joint actions involving managers, scientists and communities. Thus, it becomes important to know the man who is in direct contact with the conservation area to be involved in the management and conservation measures.

\section{CONSERVATION AREAS}

Several countries are investing in the creation of protected areas as the most efficient strategy to conserve biodiversity, natural resources and the cultural values of humanity. In these conservation areas are established several levels of protection and intervention ${ }^{4}$. Most protected areas have been created to protect species of wild fauna and flora, but they protect occasionally a considerable number of bodies of water which makes them of foremost importance for aquatic species ${ }^{5}$.

Currently, with the standard of living in urban agglomerations, population growth in increasing consumption and ancestry of nonrenewable resources, ecosystems on the planet come from losing their natural characteristics, giving way to the apparatus of what we call progress. After more than a century of the industrial revolution and the establishment of large cities, the man is questioned about the results of development. This questioning occurs through environmental fights of some organs - private or public - who took it upon himself to task to protect biodiversity for future generations.

These spaces are separated in some parts of the territory and limited land use and occupation, and the use of its resources. The protected areas are no longer seen as forbidden areas for development, but rather, for maintenance of animal and plant species, improve the water cycle and your rainfall, prevent erosion and silting of rivers, environmental education, as

\footnotetext{
${ }^{3}$ M. Gohn, Conselhos Gestores e Participação Sociopolítica (São Paulo: Cortez 2001).

${ }^{4}$ Ibid.

${ }^{5}$ A. Agostinho, et. al, Ficheries Management in Brazilian Reservoirs: Lessons from/for South America, 29 INTERCIENCIAS 334-338 (2004).
} 
well as other aspects that influence the quality of life.

The establishment of protected areas has faced great challenges. The causes of these challenges result from the way in which these areas were established, with the eviction of people living in these areas, the use of its resources, without involvement or consultation of the leaders of the communities, which resulted in social and cultural conflicts in some cases without survival alternatives.

Historically there are records of actual reserves intended for hunting of Assyrians from $700 \mathrm{BC}$ the Romans Already had their reserves to maintain their stocks of wood, among other products, to the construction of ships. Actual reserves in India were created in the 3rd century. In the middle ages, feudal lords were significant portions of their forests for timber reserves, fishing and hunting, besides serving for his fiefs.

According to Bensusan ${ }^{6}$ in the 18th century, the natural landscapes had a strong supernatural and even religious component: the sublime landscapes were those rare places where the human being would have greater chance to see the face of God. In Europe developed a different concept of protected natural area. After years of various human occupations, there had left very little of the natural environments in the Mainland.

However, the modified landscape still showed important features of scenic beauty and was being threatened by urban growth and large-scale agriculture. There were few public domain areas and the land price became unfeasible the expropriation for the creation of protected areas. The alternative was the creation of legal and social mechanisms to regulate the use of private land. Only from the mid-20th century biodiversity conservation became an explicit objective for the establishment of conservation areas.

\section{BIODIVERSITY AND IMPORTANCE OF ECOSYSTEMS}

Biodiversity is the contraction of biological diversity and is generally accepted as a synonym of species richness in an ecosystem ${ }^{7}$. LÉVÊQUE ${ }^{8}$, defines it, a little more specifically, as the scope and the differentiation of living organisms and the variety of all ecosystems and ecological complexes that involve it. Biodiversity reaches all varieties and variations of organisms and ecological systems on which include, for the organisms, genes, levels of

\footnotetext{
${ }^{6}$ N. Bensuan, Conservação da Biodiversidade em Áreas Protegidas (Rio de Janeiro, Editora FGV 2006).

${ }^{7}$ R. WhitTAKER, ISLAND BIOGEOGRAPHY: ECOLOGY, EVOLUTION AND CONSERVATION (Oxford: Oxford University Press 1998).

${ }^{8}$ C. LÉVÊQue \& J. Mounolou, Biodiversity (Wiley, Chichester 2004).
} 
populations, species and communities and, for the systems, the levels of habitats, ecosystems, landscapes, biomes and regions echo.

On diversity of ecosystems include Habitat variation in ecosystem, ecosystems in the landscape, landscapes within the biome and biomes in the biosphere; the complex of species and their physical environments; the ecological roles of biotic components in the environment; the patterns of species composition by region; the grouping of species on individualized areas; the processes and interactions in the ecosystem and among ecosystems ${ }^{9}$. Although, at first, biodiversity is applied to biology, the term can be extended beyond the biological limits integrating also the human dimension. The various languages, religious beliefs, social structures, artistic and musical demonstrations, the management practices of the Earth, the selections and forms of cultivation and any number of patterns of human societies demonstrate, with clarity, the biodiversity.

The definition of the term can be as complex as you want. Several authors present definitions, although distinct, are similar in your content. In addition to the multifaceted settings, there are several fields of interest that perceive and understand biodiversity by different perspectives. So, geneticists, ecologists, conservationists, sociologists, economists, lawyers and politicians often delimit the concepts on biodiversity to the purposes of their respective disciplines and interests ${ }^{10}$.

The Brazilian Institute of Geography and Statistics, in an attempt to condense and simplify this and other definitions published the basic vocabulary of natural resources and environment:

Total of genes, species and ecosystems of a region. Genetic biodiversity refers to the variation of genes within the species, covering different populations of the same species or genetic variation within a population. Species diversity refers to the variety of species that exist within a zone. Ecosystem diversity refers to the variety of ecosystems of a given region. Human cultural diversity can also be considered part of biodiversity, because some attributes of human cultures represent solutions to survival problems in certain environments. Cultural diversity manifests itself by the diversity of language, religious beliefs, practices, land management, art, music, social structure and selection of agricultural crops, among others. ${ }^{11}$

Researchers from the U.S. National Academy of Sciences organized in 1986, the National Forum on Biodiversity, in Washington D.C. the event needed to represent in your name, the wide range of topics and perspectives

\footnotetext{
${ }^{9}$ C. LÉVÊQue \& J. Mounolou, Biodiversity (Wiley, Chichester 2004).

${ }^{10}$ Ibid.

${ }^{11}$ The Brazilian Institute of Geography and Statistics (2004).
} 
that would be discussed and was then created the term biodiversity ${ }^{12}$.

The term has spread from the United Nations Conference on environment and development in 1992, when it was signed the Convention on biological diversity ${ }^{13}$. The Conference was held on 3 July 1992 in Rio de Janeiro-Brazil, brought together representatives of 170 countries, with the aim of examining the environmental situation in the world and the changes that have occurred since the Stockholm Conference. Some important documents were generated at this Conference, among which stand out: the Rio Declaration on environment and development, the Convention on climate change, Agenda 21 and the Convention on biological diversity.

The Convention on biological diversity, was the first major landmark that reflected the greatness of concern for biodiversity ${ }^{14}$. The Convention warned the world that the future of humanity depends on the biological resources that they have limits and that humanity has exceeded. Also, it established the need for Nations to adopt energetic measures and imminent to take care of the Earth's biodiversity and stressed that the success in safeguarding it relates to economic and social development on a sustainable basis, fair and inclusive. ${ }^{15}$

The Convention on biological diversity defines biodiversity as the variability of all living beings from any source, including terrestrial, marine and aquatic, and the ecological complexes of which they are part, which includes diversity within species, between species and of ecosystems.

Today we don't know the number of species of different kingdoms. Currently, about 2 million have already been classified, but it is estimated that the total number may vary between 5 and 50 million species in the world. ${ }^{16}$ Although the estimated total is small close to the more than 500 million that ever lived on Earth, there is more alive today than at any time in the past. It's a paradox explained by biological diversity. A missing species leads to the emergence of several others, which, for your time, dismembered,

\footnotetext{
${ }^{12}$ V. J. Wilson, BIODIVERSity OF HWANGe NATIONAL PARK-PART I: LARge MAMMALS AND CARnivores PReliminary Analysis RePORT, 233 pages (Chipangali Wildlife Trust \& Dept. of National Parks \& Wildlife Management 1997).

${ }^{13}$ C. LÉVÊQue \& J. Mounolou, Biodiversity (Wiley, Chichester 2004).

${ }^{14} \mathrm{~J}$. McNeely, Critical Issues in the Implementation of Convetion on Biological Diversity, in WidDENING PERSPECTIVE ON BIODIVERSITY (Krattiger Analote F. et al, Switzerland: IUCN/International Academiy of the Environment 1994).

${ }^{15}$ C. Horowitz, A Sustentabilidade da Biodiversidade em Unidades de Conservacao de Protecao Integral: Parque Nacional de Brasilia. Tese de Doutorado em Densenvolvimento Sustentavel, 329 pages (Universidade de Brasilia 2003).

${ }^{16}$ V. J. Wilson, Biodiversity OF HWANGE National PARK-PART I: LARge MAMmals AND CARNIVORES PRELIMINARY ANALYsis RePORT, 233 pages (Chipangali Wildlife Trust \& Dept. of National Parks \& Wildlife Management 1997).
} 
giving rise to successive descendants' groups $^{17}$.

Government authorities, non-governmental organizations and international bodies, have failed in efforts to inform communities of the meaning and importance of biodiversity for the maintenance of the life of human beings. Maybe it happens because the authorities were not yet able to protect biological diversity in the countries with more biodiversity. The reason anthropocentric more important to preserve biodiversity is the role that micro-organisms, plants and animals play in providing free services to the ecosystem, without which society, in your current form couldn't last ${ }^{18}$.

The man grows and consumes in mass quantity, nothing more than 9 types of plant species that form the basis of humanity ${ }^{19}$. There is an immense potential of biodiversity has not yet explored by humans. Wild plants are tested chemically, in search of new drugs that are beneficial to mankind. Of the very few plants chemically examined, scientists estimate that $10 \%$ contain substances that can be used in cancer treatment. This means that humanity will potentially benefit of the countless existing species. The World Health Organization - who estimates that $80 \%$ of people in developing countries in the world depend on traditional medicine for their basic health needs, and that approximately $85 \%$ of traditional medicine involves the use of plant extracts ${ }^{20}$.

The plants of tropical forests can be useful for modern agriculture in three different ways: as a source of new crops that can be grown; as a source for breeding of improved varieties of plants; and as a source of new biodegradable pesticides $^{21}$. The properties of biological diversity imply great resilience for ecosystems and organisms and are described as a benefit arising out of the services of ecosystems the biosphere.

The Ecosystems are responsible for several invaluable services, among which we can highlight:

- the maintenance of quality soda from the atmosphere, which helps to stabilize the climate and lessen the time;

- control of the hydrological cycle, including the reduction of flooding and damaging droughts;

\footnotetext{
${ }^{17}$ Ibid.

${ }^{18}$ P. R. Ehrlich \& A. H. Ehrlich, The Population Explosion: Why We Should Care and What We Should Do about It, 27 ENVIRONMENTAL LAW 1187-1208 (1997).

${ }_{19}^{19}$ J. Diamond, Armas, Germes e Aço: os Destinos das Sociedades Humanas (Rio de Janeiro, Record, 2005).

${ }^{20}$ C. Horowitz, A Sustentabilidade da Biodiversidade em Unidades de Conservacao de Protecao Integral: Parque Nacional de Brasilia. Tese de Doutorado em Densenvolvimento Sustentavel, 329 pages (Universidade de Brasilia 2003).

${ }^{21}$ M. Plotkin, A Perspectiva Para os Novos Produtos Agrícolas e Industriais nos Trópicos, in Biodiversidade - Rio de Janeiro: Nova Fronteira (E. O. Wilson (Org), 1997).
} 
- the protection of coastal areas by originating and conserve coral reefs and sand dunes;

- the formation and conservation of soil fertility, which are essential for agriculture and forestry;

- the storage and cycling of nutrients;

- the dispersion and absorption of pollutants;

- the potential crop pest control and disease vectors;

- the maintenance of ecosystems that rehabilitate other areas when catastrophic events occur unpredictable as hurricanes, fires and other disasters of human causes ${ }^{22}$.

In the face of growing human pressure on the environment, all these benefits should encourage strongly the nature conservation actions. The most precious value and the most intangible of biodiversity is her result of long evolution of life on Earth, in the solar system, due to accumulation of processes triggered by life itself ${ }^{23}$.

Giving monetary value to these invaluable services has proven difficult as they are not recognized by market values, which tend to be based on economic analyses ${ }^{24}$. Still, environmental economists strive in this direction because it is believed to be an important tool in the task of persuading managers in public policy development for biodiversity. It is estimated the annual value of the environmental services in values ranging from USD \$18 to $\$ 61$ trillion. These values are similar to annual gross domestic product $(\mathrm{GDP})^{25}$.

The species are worth together and as unique individuals. The "value in use" is designated as that pertaining to what can be bought and sold on the market. For the plant species or animals that still do not have utility as merchandise, but that may one day be deemed the "option value" 26 . However, very little is known about biological diversity and therefore it is difficult to conceive of values for the same. Of all species of plants, animals and microorganisms known, only a small part has been used by $\operatorname{man}^{27}$.

If you focus the analysis on economic aspects and knowing that

\footnotetext{
${ }^{22}$ H. A. Mooney \& Dry Tropical Forests (S. H. Bullock \& E. Medina eds., Cambridge: Cambridge University Press).

${ }^{23}$ V. J. Wilson, Biodiversity of Hwange National PARK-PART I: LARge MAMmals AND CARnivores Preliminary ANALYsis RePORT, 233 pages (Chipangali Wildlife Trust \& Dept. of National Parks \& Wildlife Management 1997).

${ }_{24}^{24}$ A. Balmford, et al. Economic Reasons for Conserving Wild Nature, SCIENCE v. 297 (2002).

${ }^{25}$ Ibid.

${ }^{26}$ J. Mota, O Valor da Natureza: Economia e Política dos Recursos Naturais, Rio de Janeiro: Garamond (2001).

${ }^{27}$ J. Diamond, Armas, Germes e Aço: os Destinos das Sociedades Humanas, Rio de Janeiro, Record (2005).
} 
biodiversity is the basis of all agricultural activities, livestock, fisheries, forestry, medical and pharmaceutical, one can say that these activities move and sustain the economic systems of modern societies. Income from tourism and ecological leisure reaches values that qualify biodiversity the heights of difficult measurement: the pleasure of enjoying, contemplate and admire the charms and Splendors that the richness of scenarios and ways of life.

\section{TROPICAL DIVERSITY}

The tropical areas are concentrated the higher rates of biological diversity ${ }^{28}$. Some theories attempt to explain the reasons of this phenomenon: the chances of time, climate stability, the spatial heterogeneity of competition and predation are some of the most accepted theories. The hypothesis of time states that, as the tropical environments are older than the Arctic and temperate environments, their species had more time to evolve and diversify ${ }^{29}$. Climate stability hypothesis says that tropical regions were less disturbed by successive glacial periods in the last 65 million years. The continuous dry ice age species restricted to the geographic isolation increasing variety of species ${ }^{30}$.

The spatial heterogeneity establishes that the highly diverse habitats favor the increase of diversity, since they offer larger combinations of micro habitats and ecological niches. The competition hypothesis argues that in the tropics there is greater competition between agencies, which leads to increasing your expertise in the use of available resources.

Mozambique located on the eastern coast of Africa, is part of countries with species diversity of tropical ecosystems and has ecosystems of great ecological, social and economic value. It has various areas considered of foremost importance biologically, known as "Hotspots" of biological diversity and with a natural resources biodiversity ${ }^{31}$. The characterization of ecosystems was based on categorization on system developed by the World Wildlife Foundation (WWF) called eco regions, with three main categories, namely: (i) eco land regions, (ii) eco and marine and coastal regions, (iii) eco regions of fresh water systems.

Mozambique has a remarkable network of protected areas and consists

\footnotetext{
${ }^{28}$ V. J. Wilson, BIODIVERSity OF HWANGe NATIONAL PARK—PART I: LARge MAMMALS AND CARnivores Preliminary ANAlysis Report, 233 pages (Chipangali Wildlife Trust \& Dept. of National Parks \& Wildlife Management 1997).

${ }^{29}$ R. RickLEFs, A ECONOMIA DA NATUREZA, 470 pages (3a. Ed. Rio de Janeiro, Guanabara Koogman 1996).

${ }^{30} \mathrm{Ibid}$.

${ }^{31}$ IUCN (2005).
} 
of 6 national parks, 5 wildlife reserves, 14 forest reserves and 12 hunting preserves, covering a total area of about $128,749 \mathrm{~km}^{2}$ the equivalent of $16 \%$ of the national territory. Despite the extension of conservation areas, only a small part of the diversity of habitats and ecosystems that the country possesses lies within these areas. This network of conservation areas was established in the period between 1950 and 1970, at a time when the conservation objectives had another meaning. For example, the forest reserves were at your most established as extractive reserves, serving to produce wood.

At the United Nations Conference on environment and development (UNCED) held in Rio de Janeiro-Brazil in 1992, the issues relating to biological diversity, they deserve a great deal of attention, which resulted in the establishment of the Convention on biological diversity. With the signature of this Convention and any conservation movement that followed the Rio Summit, nature conservation has gained a new dimension which forced the need to adjust the initial objectives that guided the creation of protected areas.

The strategy of implementation of the Convention on biological diversity is of a particular importance for the management of these areas, and investments needed for your restoration and conservation. Thus, the National Conservation Areas Agency, has a great challenge to establish a management model involving all stakeholders including local communities and community leaders who live in these areas.

In Mozambique, studies conducted to date identified several areas of great importance in biodiversity, which are considered as being Hotspots of biological diversity. The most notable are:

\section{A. Gorongosa Mountain-Rift Valley}

This region extends from the Mountains of Gorongosa (isolated hill with an altitude of 1863 meters); the southern region of Cheringoma plateau of the African Rift Valley at an altitude of 300 meters, consisting of marine sediments from the period of the Quaternary; the coast of mangrove and the Prairies and wetlands of delta of Zambezi River.

Mount Gorongosa is located $160 \mathrm{~km}$ from the sea and the only elevation present throughout the region, which reinforces the rise of humid winds that result in heavy rain above mountainous terrain with $2,000 \mathrm{~mm}$, year. Mount and coated with habitats ranging from tropical rainforests to mountain rainforests with grasses in their summits.

In areas of higher altitude, this type of vegetation is generally 
characterized by the combination of Cassipoureamalosana, Nuxiacongesta, Podocarpuslatifolius and species below the canopy, as theiformis Aphloeia. The Acacia forest comprises the communities of scattered trees and bushes where the Acacia nigrescens is the dominant species in the arboreal layer/Bush. An important spot extends to the North on the slopes of "tandos" the plains of Urema Lake.

This variety of habitats can find endemic species of plants and animals; such as: The Pope head green figs (Oriolischlorocephalus subspecies speculifer), the mountain Robin Pinto (spot-orostrythus), the Chirindaapalis (Apalischirindensis) which is a species of restricted range, Robin Woods of Swynnerton (Swynnertonianswynnerton) and subspecies of car white breast (white-chested Alethe), among other species.

\section{B. Chimanimani Mountains}

This region is in the East of the Continental Interior Plateau of CentralSouth Africa along the border of Mozambique and Zimbabwe, and extends over a length of $40 \mathrm{~km}$ with an altitude above $800 \mathrm{~m}$. This Massif is characterized by an outstanding diversity of habitats and species.

Close to 1,000 species of vascular plants have been recorded in this area, of which 45 (4.5\%) are endemic. About of 5 species of the genus Aloe (a. munchii, a. mazeliana, a. howmanii, a. plawsii and a. wildii), 3 species of Erica (e. Lanceolifera, e. Pleiotricha and e. Wildii) and 2 species of the genus Protea ( $p$. Crinita and p. Enervis) are endemic.

More than 160 species of birds have been recorded in Chimanimani, some of which are also considered endemic to mountainous regions of East Africa.

Robin Woods of Swynnerton (Swynnertonianswynnerton) inhabits humid forest elements of the mountain that highlights the faunal relationships that exist with other staple areas (example - the Arch of the Eastern mountains of Tanzania). Other species of rare birds that occur in the moist forests of the massif of Chimanimani District include cobreirabarrada Eagle (Circaetusfrasciolatus), Tuta dark (Andropadusimportunis), Shoelace chestnut-fronted (Prionopsscopifrons) and Batid and Woodward (Batisfratrum).

\section{Centre of Endemism of Maputoland}

This Maputo land region with approximately of $26,734 \mathrm{~km}^{2}$, extends from the southern part of Mozambique to the northeast of the province of Natal, in South Africa. It is characterized by the variety of Lakes such as the 
Lakes Piti, Xingute and Satine in Mozambique and South Africa side.

A center of plant endemism was proposed by Van $\mathrm{Wyk}^{32}$ on the coast of the Indian Ocean, which was called Maputoland-Pondoland region. This region is diversified and complex in terms and floristic however, two outbreaks with high endemism, notably the Maputoland Centre (MC) and the Pondoland Centre (PC).

Van Wyk (1994) suggested that at least 1,100 species of vascular plants occur in the center of Maputo land, but this number can reach up to 2,000 to 3,000 species; of these, at least 186 species and 4 genera, including Brachychloa, Ephippiocarpa, Helichrysopsis and Inhambanella are endemic or nearly endemic. Most of them are rare and little known.

The fauna associated with this biodiversity is interesting and very rich. Of the more than 472 bird species at the Maputo land, 47 are endemic subspecies/almost endemic. Others include 14 mammals (102 species, about 4 locally extinct), 23 reptiles (about 112 species/subspecies), 3 frogs (45 species/subspecies) and 7 freshwater fish (67 species).

\section{LOSS OF BIODIVERSITY AND HABITAT FRAGMENTATION}

The evolutionary biologists and conservationists have returned their attention to tropical forests for 2 main reasons: 1) while $7 \%$ of the land area covering, they contain more than half of the species of biota; 2) these forests are being destroyed so quickly that they probably will disappear in the 21ST century $^{33}$.

In any discussion about biodiversity, rainforests must occupy the main place. Broadly defined, these forests are home to two-thirds of the world's organisms, a number that reaches no less than 3 million, and that can be 10 or more times bigger than this. Impressive, however, is the fact that only about 500,000 species of tropical and subtropical regions of the world have names and have been catalogued in the scientific literature ${ }^{34}$.

Biologists have long recognized that the full set of biological diversity will never be fully known-that is, not all species and ecosystems will be identified, named, catalogued and studied in detail before many of them disappear. For example, it is possible that there are well over 10 million

\footnotetext{
${ }^{32}$ A. Van Wyk, Biodiversity of the Maputaland Centre, in THE BIODIVERSITY OF AFRICAN PLANTS 198-207 (L. J. G. Van Der Maesen, et al. eds. 1996).

${ }^{33}$ V. J. Wilson, Biodiversity of HWANGE NATIONAL PARK-PART I: LARGE MAMMALS AND CARNIVORES PRELIMINARY ANALYsis RePORT, 233 pages (Chipangali Wildlife Trust \& Dept. of National Parks \& Wildlife Management 1997).

${ }^{34}$ P. RAVEn, River Habitat Survey: A New System to Classify Rivers ACCORDing to Their HABITAT QUALITY (1997), https://www.researchgate.net/publication/270274631.
} 
species alive today. Only 1.4 million have already been described and named, and those that have been studied fully for potential use by humans are only a tiny fraction of that number ${ }^{35}$.

There's no way to know for sure how much diversity is being lost in the tropical forests. We don't know even how much biodiversity exists, because very few species are monitored ${ }^{36}$. There are 4 main reasons for the number of species by reducing human actions: 1) direct predation by man, 2) introduction of alien species, 3 ) dispersion of diseases, and 4) degradation or loss of Habitat ${ }^{37}$. Through a process closely linked to the recent loss of biodiversity, human society has expanded and developed. Considering this reality, it has justified this loss as an inexorable process for the rise of humanity ${ }^{38}$.

The estimates project results concern, indicating that, if the rate of destruction of forest ecosystems is maintained over the next few years, the rate of extinction will rise to a level of 1,000 to 10,000 times more than the expected natural extinctions ${ }^{39}$. In other words, a loss between 20 to $50 \%$ of the species on the planet for the next century; and, for the next 30 years, a total of 7 million of species will disappear. Even if it were possible to suspend all activities that come affecting natural ecosystems remaining, this cycle of extinction was to last for at least 50 years ${ }^{40}$. At the moment when one realizes that a body is in danger, usually it's too late to save him. Stopping the loss of diversity is very difficult.

What will happen if the decimation continues? The harvests of crops will be more difficult, due to factors such as climate change, soil erosion, loss of water, Pollinator decline, and increasingly severe attacks of pests. The conversion of productive land in wasteland if you accelerate, the deserts will grow. Air pollution will increase, and the local weather will be more severe. As the ecosystem services they start missing, mortality from respiratory and epidemic diseases, natural disasters and especially hunger

\footnotetext{
${ }^{35}$ G. Steven \& J. Burley, 3000 Raw Ideas Commercial Success, RESEARCH AND TECHNOLOGY MANAGEMENT (May-June 1997).

${ }^{36}$ V. J. Wilson, BiOdiversity OF Hwange National PARK-PART I: LARGE MAMMALS AND CARnivores PReliminary ANALYsis RePort, 233 pages (Chipangali Wildlife Trust \& Dept. of National Parks \& Wildlife Management 1997).

${ }^{37}$ R. WhitTAKER, ISLAND BIOGEOGRAPHY: ECOLOGy, Evolution AND CONSERVATION (Oxford: Oxford University Press 1998).

${ }^{38}$ C. Horowitz, A Sustentabilidade da Biodiversidade em Unidades de Conservacao de Protecao Integral: Parque Nacional de Brasilia. Tese de Doutorado em Densenvolvimento Sustentavel, 329 pages (Universidade de Brasilia 2003).

${ }^{39}$ V. J. Wilson, Biodiversity OF Hwange NATIONAL PARK-PART I: LARGE MAMMALS AND CARnivores PRELIMINARY ANALYsis RePORT, 233 pages (Chipangali Wildlife Trust \& Dept. of National Parks \& Wildlife Management 1997).

${ }^{40}$ Ibid.
} 
will decrease life expectancy, not to mention a cure for cancer may have been lost with the loss of organisms ${ }^{41}$. To lead to death the vast collection of existing beings, humanity will be liquidating the invaluable heritage inherited, wasting the enormous potential of use that species offer ${ }^{42}$.

\section{PARTICIPATORY MANAGEMENT OF CONSERVATION AREAS}

There are several conceptions of participation and to begin consideration of this concept, the definition will be used by Avelar ${ }^{43}$.

Participation is a Latin word whose origin dates back to the 15th century. Comes from participacionis, participatum, participatio. Means "take part in" share, join the feeling or thought. Understood succinctly, is the action of individuals and groups with the aim of influencing the political process. Broadly, "participation is the action that develops in solidarity with others within the State or a class to modify or conserve the structure (and therefore the values) of a system of dominant interests"

What is participatory management? To try to understand the different meanings that are attributed to that term and without depleting the discussion, we need to reflect first on other terms and concepts that, for the most part, appear so associated in the speeches, such as: participation, democracy, citizenship, social representation, autonomy, communication, collective, building consensus. All these somehow relate to the so-called participatory management, now giving meaning and understanding, sometimes bringing reflection and critique about your meaning and practice.

When we talk about management we refer generally to a set of tasks that will allow us to manage the resources that we have available, to what was previously planned, so that the goals that we have set may be reached. And participation? Participating means being part of, share with, intervene in, if evolver. Is related to take responsibility, to exercise citizenship, build actions along with the other, is willing to open dialogue, respecting diversity, reflective awareness exercise and the ability to live and act autonomously. Participating means a constant search for the emancipation of the subject, it

\footnotetext{
${ }^{41}$ P. R. Ehrlich \& A. H. Ehrlich, The Population Explosion: Why We Should Care and What We Should Do About It, 27 ENVIRONMENTAL LAW 1187-1208 (1997).

${ }^{42}$ V. J. WiLSON, BIODIVERSITY OF HWANGE NATIONAL PARK-PART I: LARGE MAMMALS AND CARnivores Preliminary ANALYsis RePort, 233 pages (Chipangali Wildlife Trust \& Dept. of National Parks \& Wildlife Management 1997).

${ }^{43}$ L. Avelar, Participação Política, in Sistema político brasileiro: uma introdução (L. E. Avelar \& A.C. Cintra eds, São Paulo: Editora Unesp 2004).

${ }^{44}$ Ibid.

${ }^{45}$ A. Pizzorno, Condizioni Della Participazione Política, in Le Radici Della Politica Assoluta (A. Pizzorno ed., Milano, Feltrinell 1966).
} 
means to be "author of your own story", from the reflection on your role as a citizen.

Thus, a Committee of a conservation area, while public space that incorporates the participation of society as one of its foundations, not satisfied just legally bureaucratic level. It requires, too, at the political level, the citizen action, legitimate and organize a wide range of social actors. Thus, regulating environmental management processes that consider and value dimension of social participation in your structure, it does not guarantee your effectiveness, you need to be conquered mostly by people and institutions (in the case of those committee's community leaders) that, at the time they assume this role, commitment to share the responsibilities of managing natural resources protected by conservation area.

For Sachs (1986), the indicators of participation are: the power of the Community initiative; the space for real experiences; the degree of symmetry in the civil society relations with the various levels of Government and market forces; existing mechanisms for conflict resolution and agreements; the nature of the planning process. Arnstein ${ }^{46}$ created the "ladder of citizen participation", which promotes participation in eight levels (therapy, handling, information, consultation, peace, partnership, empowerment and citizen control). Pimbert and Pretty ${ }^{47}$, for your time, have created the "typology of participation", graduating from it in seven types (passive participation, participation, participation information extraction for consultation, participation by material incentives, functional participation, interactive participation and mobilization).

For $\mathrm{GOHN}^{48}$, it is not the Community Committee itself that informs us about your nature, but rather the process in which it is inserted:

The community committees, can be both valuable instruments for the establishment of a democratic and participative management, characterized by new patterns of interaction between Government and society around sectoral social policies, as may be too formal bureaucratic structures and/or simple links of transmission of social policy drawn up by domes, mere structures for transfer of resources for the community taking the burden of administering them; or settling of conflicts and instruments of integration of individuals in pre-defined schemes. ${ }^{49}$

\footnotetext{
${ }^{46}$ Arnstein, Uma Escada de Participação Cidadã, in Revista Participe. Rio de Janeiro: Associação Brasileira de Promoção da Participação (2002).

${ }^{47}$ Pimbert and Pretty, Parques, Comunidades e Profissionais: Incluindo "Participação" no Manejo de Áreas Protegidas, in Etnoconservação: Novos rumos para a proteção da natureza nos trópricos (A. C. Diegues ed. São Paulo: Hucitec 2000).

${ }^{48}$ M. Gohn, Conselhos Gestores e Participação Sociopolítica (São Paulo: Cortez 2001).

${ }^{49}$ Ibid.
} 
The particular case of Mozambique, which in recent decades has been characterized by armed conflict and by the poverty of its inhabitants, has in your story (as we hope will have in the future) a past famous for vast and densely populated plains by animals such as lions, elephants, Zebras, rhinos and hippos.

"The experiences of community conservation" held in southern Africa embraces a wide variety of guidelines, which are based on forms of passive participation, where communities have a limited control over the decisionmaking stages, for a full and direct participation in the management resources, set active participation. Between these two extremes there are various combinations, which stimulated the discussion in the scientific context, as well as the identification of various classifications, which have focused on various aspects, including the level of participation, the ownership or the participatory approach or contract. ${ }^{50}$

The acceptance of conservation projects divided among a population that is an opportunity for a better life and a population who questions the fact of being forced to change her life, breaking with traditions eventually relevant to your emotional, social and religious balance.

Another issue crucial to bear in mind to convince local people to join the project may be in the fact that wildlife can potentially be more competitive than other forms of land use, particularly in dry savanna and with little potential for agriculture or pasture for livestock.

This is the idea of change, especially for the younger ones, as is the greater adherence to conservation projects, in particular gives the possibility to be able to get a job in the various activities of the conservation area. A generalized ambition and seen to have a more comfortable life. On the other hand, the situation of peace in Mozambique and economic growth has increased the space and the sensitivity for the exploitation of its natural resources, particularly with regard to the recovery of the national parks.

... Rural populations should be provided with appropriate tools to enable them to take the reins of conservation, as rightful owners of your territory, highlighting at the same time, the knowledge and the traditional knowledge, which for centuries have regulated the symbiotic relationship between man and nature. $^{51}$

\footnotetext{
${ }^{50}$ S. Belloti, Meio Ambiente e Turismo Sustentável em Moçambique: Organização Territorial e Conhecimentos Culturais no Parque Nacional do Zinave, Università degli Studi di Bergamo/Università degli Studi di Napoli “L’Orientale”, IICT - Instituto de Investigação Científica Tropical, Lisboa (2012).

${ }^{51}$ Ibid.
} 
Mozambique, as a signatory to the Convention on biological diversity, undertook to promote the development of areas of conservation, through participatory processes of planning, administration and management of protected areas. The methodology of participatory management generates a favorable environment for greater efficiency and effectiveness in the activities that develop for the conservation of biological diversity and integration of local communities, the private sector and other actors of civil society, engaged in the conservation of nature.

This methodology of participatory management, focuses on the basis of some principles that address issues of ownership of resources, conservation planning, use of resources, associated with the presence of communities within or around protected areas, administration and management, investment promotion, treatment of the sector national and private participation of other partners.

The principles that guide the conservation, restoration and management of protected areas, the legal framework in Mozambique are:

\section{- Property of natural resources}

The natural resources in the soil and subsoil, the internal waters, the territorial sea, the continental shelf and the exclusive economic zone are owned by the State;

\section{- Sustainable development}

Development must be based on environmental management that meets the needs of the present generation without compromising the environmental balance, allowing future generations to also meet their needs;

- Sustainable exploitation of natural resources

Forest resources and wildlife should be used rationally and controlled through the application of scientific and technical knowledge, to achieve conservation objectives for present and future generations;

- Integration of local communities and the private sector

The economic and social development policies and biodiversity preservation should involve local communities, the private sector and civil society in general, to achieve sustainable development in the present without commit future generations;

- Establishment of partnerships and international cooperation

Promotes harmonious solutions consultation with international organizations, the protection, conservation and management of forest resources and wildlife.

For example, the complexity of the conservation project of the Gorongosa National Park in Mozambique, including the expectations of the program of restoration of the eco-system versus the expectations of local 
population, the project successfully will be found if the collective moral and ethics can be defining one for the mutual understanding that will generate mutual benefits. Thus, the ethical and moral sense, based on a natural consciousness of otherness, intensifies the concept of useful ${ }^{52}$.

A utility is required in view of the widespread recognition of the damage caused by a fractured planning. The current network of projects was established through an idea of sharing benefits with local communities and continuity in the ecosystems influences, resulting from a participatory management with involvement of local communities that live in this area.

The holistic evolutionary approach is used in the Gorongosa thesis III which de-emphasis is on the salient reciprocal relations and kinetic succession of land surfaces and biotic communities, influenced by landscape processes and prime mover components. ${ }^{53}$

Understanding the landscape that influences and correlates is the basis of research work of the Ecologist Kenneth Tinley. What is proposed in this work is that this idea and correlation between systemic and dynamic elements be extended to a territory that is beyond a supposedly "natural" ecosystem, and thus apply to all places.

One can question the ability of man to organize for better management of the territory, having regard to the past of a story that is clearly predatory, as well as the existing differences and complexity of motivations in their actions. The answer is perhaps no longer solely in a morality of the problem but in the fact that this is a growing and pervasive problem, which could transform the common idea about a utopian demand a consciousness in emergency and able to mobilize the world.

\section{CONCLUSION}

The debate on the environmental problems of our day is related to the speed and the intensity of the changes of natural environment imposed by the dynamics of contemporary societies, incompatible with the maintenance or the reproduction of the ability of global support for your time implies reducing the possibilities of future generations. Thus, it is important to not only the intensity of the predatory effects that promote the ongoing extinction of species, but also the speed of the changes imposed by the current economic rationality that makes it impossible for any adjustment and gradual evolution of the species.

\footnotetext{
${ }^{52}$ R. Aguiar, Direito do Meio Ambiente e Participação Popular (Brasília: Edições Ibama 2002).

${ }^{53}$ K. TINLEY, FramewORK OF THE GORONGOSA ECOSYSTEM, MoZAMBique, D.Sc thesis, University of Pretoria, South Africa (1977).
} 
The dynamics imposed by society on the environment contributes synergistically to the reduction of environmental quality and the sustainability of ecosystems that make up the larger system, since the stability of these remains through complex mechanisms that depend on the variety of its elements, among other factors.

The application of the techniques of community participation can assist managers of protected areas to find the key factors for the development of a conservation strategy coupled with social development. The dissociation between conservation and development, so characteristic of traditional models of creation and implementation of protected areas, has shown great weaknesses.

The use of methods that promote the participation of the communities could allow an understanding of the differences and conflicts between the institutions involved and the different social groups, leading to the design of agreements aiming to find particular solutions to each socio-economic and ecological context. On the other hand, it can be raised conflicts, which, if not managed constructively, it can intensify disagreements and compromise even more the links between protected areas and communities.

Territoriality, while integrative synthesis between the natural and the human, historical and spatially localized, makes essential a participatory management of conservation areas in countries like Mozambique, as it allows the understanding and the transformation of social relations that are performed from a given mode of production and organization established in a defined space.

The sense of from the social groups in situation of environmental vulnerability is to highlight the reality of the majority, to democratize access to information and understand society in its multiple contradictions. By State of social and environmental vulnerability, we understand the situation of specific groups which are: (1) to a greater degree of direct dependence of natural resources to produce, work and improve living conditions; (2) excluded from access to socially produced public goods; and (3) absent from legitimate participation in decision-making processes with regard to the definition of public policies that interfere with the quality of the environment in which they live.

To achieve local conditions mentioned above, it is important to understand the situation of education in Mozambique and to your relationship with other activities that inhibit or promote, in the sense of democratic guarantees that everyone should enjoy, as well as the complete set of basic goods and services essential to the social well-being, in line with the balance of the ecosystems that we are saved. 
Thus, the participatory management of conservation areas is based on multidisciplinary and looks for five dimensions of sustainable development, namely: political, social, economic, cultural, ecological, and geographical. The fundamental tools of participatory management of conservation areas, are the Committees of Community Management of Natural Resources created in the communities living around protected areas. The representativeness of these committees in the organs of each conservation unit manager, enables effective people's participation in making decisions and their implementation. 